\title{
Trends in Tobacco Consumption \\ - a Comparative Analysis of WHO European Region Countries
}

\author{
Adam Mateusz Suchecki
}

Ph.D., University of Lodz, Lodz, Poland, e-mail: adam.suchecki@uni.lodz.pl

\begin{abstract}
Tobacco consumption, as well as the consumption of any other psychoactive substances, lead to addictions, which is a serious problem that modern societies have to face. To reduce the negative consequences of nicotine consumption and to provide sustainable development, many governments, in both developed as well as developing countries, adopt policies to reduce tobacco production and consumption. For example, they implement various health programs to combat addiction, and they also provide appropriate financial and fiscal resolutions. Any actions taken at different decision-making levels are often bounded with economic and financial policies of a particular state, including fiscal policy.

State interventionism concerning tobacco is most visible in developed countries such as the US, Canada, and European Union countries. Developing countries and Asian countries have also started to introduce regulations concerning tobacco consumption on a large scale in response to the negative effects of nicotinism.

The main aim of the paper is to show consumption trends as well as the fiscal and price policies of tobacco products. The theoretical part is supplemented by data from reports and analyses presented by the World Health Organization (WHO).
\end{abstract}

Keywords: Tobacco, Tax, public policy

JEL: H71, I18 


\section{Introduction}

Nowadays, smoking is one of the biggest problems of public health and one of the greatest threats to civilization. It is connected with the prevalence of smoking as well as losses incurred by society, and also indirectly by the economy, which has to bear the costs of treating people suffering from illnesses that result from smoking. Smoking is generally considered an addiction, and the mechanism of nicotine effects is similar to the effects of highly addictive substances such as cocaine or heroin (Tubek 2003, pp. 33-34).

Nicotinism is an addiction in which two types of addictions - pharmacological and behavioral - overlap. Pharmacological addiction is related to the need to maintain a specific concentration of nicotine in the blood serum. By contrast, behavioral addiction is an effect of psychological, environmental, cultural, and social factors. What plays a crucial role in someone starting to smoke is the example of parents, teachers, and peers who smoke, as well as advertisements for cigarettes. Additionally, social acceptance of such behavior in the family, closest friends, or place of work foster smoking (Samochowiec, Rogoziński, Hajduk, \& Skrzypińska 2001, p. 327).

A significant social and economic problem is not just the fact that smoking is harmful to the smoker, but it also leads to the secondary addiction of people inhaling tobacco smoke as a result of passive smoking. Smoking, both active and passive, has a negative effect on health and health-related costs (costs of treatment) as well as on the financial status of smokers (there is a bigger financial burden for smokers and their families) and the economy (a decrease in productivity and employment, absence of working-age people who smoke due to illnesses and premature deaths).

Smokers are not only exposed to the effects of nicotine but also to the effects of over 4000 other chemical substances. Tobacco smoke can cause cancer in 14 locations in the body. A strong cause and effect relationship is observed in the occurrence of malignant neoplasms of the lungs, pharynx, throat, mouth, renal pelvis, urinary bladder, and pancreas. A weak cause and effect relationship was confirmed in the occurrence of malignant neoplasms of the stomach, nose, lips, liver, kidney, and also with leukemia. What is more, smoking markedly increases the risk of cardiovascular diseases and respiratory diseases, and it has a negative influence on fertility, the weight of newborn babies and can also be a cause of sudden infant death syndrome (Samochowiec, Rogoziński, Hajduk, \& Skrzypińska 2001, p. 324).

All of the abovementioned factors confirm that tobacco is a substance that can be considered socially undesirable, and its distribution and consumption should be restricted by implementing appropriate public policies. In the majority of countries, it is the state that has a monopoly on the production and distribution of tobacco products. It results in a conflict of interest as, on the one hand, consuming tobacco products has devastating effects on public health and the economy; on the other hand, the profits from distribution are a significant source of budget income (Rosiński 2014, p. 91). However, in the long run, restricting the consumption of tobacco products results 
in reduced costs of tobacco-related illnesses as well as prolonged economic productivity of society along with the extended active professional life. Therefore, a restriction on smoking is in the public interest.

In order to restrict the consumption of socially undesirable goods, the public sector can take advantage of a number of tools. They include imposing excise tax, a ban on tobacco advertising, as well as restricting sales and consumption of tobacco products to specific legally designated places (Folland et al. 2011, p. 933).

\section{A review of the literature}

The main aim of the paper is to show how particular economic instruments, such as pricing policy and fiscal instruments, influence the consumption of legal tobacco products as well as the development of illegal sources of their distribution. Similar studies were conducted in various parts of the world in countries that differed in terms of economic development and culture. This type of research is of particular importance for less developed countries as it is in these countries where a large part of the global market for tobacco goods is concentrated. According to a report by Tobacco Atlas concerning the global consumption of tobacco products, although the number of cigarettes smoked is falling, many tobacco companies expand into densely populated Asian countries (about $40 \%$ of all cigarettes in the world are smoked in China). The biggest increase in the number of cigarettes smoked connected with this expansion is observed in Africa and in countries of the Eastern Mediterranean Basin (https://to baccoatlas.org/, accessed: 20.07.2019).

One Asian country that has battled to combat the nicotinism epidemic among its citizens is Thailand, where the excise duty on cigarettes was raised in 2009. Husain et al. published an article in which they present the results of studies concerning the effects of the tax increase there in two selected years: 2009 and 2011. In the study, a logit regression model was used to examine the correlation between the change in the price of cigarettes in specific pricing categories and their consumption in two regions of Thailand. The results clearly show that, together with an increase in cigarette price due to the tax raise, the number of cigarettes smoked did not fall. This was mainly because consumers gave up smoking expensive brands of cigarettes whose prices increased most in order to buy cheaper ones (Jami et al. 2017, pp. 4-9).

A similar study was conducted in Spain in 2018. Unfortunately, the results from this study are similar to the ones mentioned above - an increase in cigarette price connected with a tax increase on tobacco goods does not markedly influence the number of smokers because together with a fall in cigarette consumption, the consumption of cheaper substitutes increases, including cut tobacco (Burguillo, Romero-Jordán, \& Sanz-Sanz 2019, pp. 1-8).

In contrast to the abovementioned results, Blecher describes high taxes on alcohol and tobacco as an effective method to reduce the consumption of these substances 
in society. He suggests that similar solutions should also be used for sweetened beverages, which is the reason for the obesity epidemic in developed and developing countries (Blecher 2015, pp. 175-179). He explains the effectiveness of fiscal changes introduced in South Africa to reduce the number of smokers with a form of imposed tax. In this case, we are dealing with a rate assigned to every cigarette, not a percentage of their price. So, it limits the possibility of finding a cheaper substitute in the form of other, cheaper cigarette brands or cut tobacco. Such a solution is also less profitable from a fiscal point of view, as taxes with such rates are generally simpler to collect and thus are an effective source of budget income.

In turn, in the article by $\mathrm{Hu}$ and Mao, one can find an interesting analysis of the problem of consuming tobacco products in China from the perspective of the state budget. The authors, based on research, claim that increased cigarette prices resulting from an increased tax rate from 40\% to 50\% between 1980 and 1997 meant that state budget losses doubled in respect of tax income from tobacco growers and local taxes. On the other hand, increasing the tax rate by $10 \%$ could help save between 1.44 million and 2.66 million lives (Hu \& Mao 2002, pp. 105-108).

Slightly different conclusions are presented in the report concerning nicotinism in Poland (Czart Ciecierski, Cherukupalli, \& Weresa 2011). It shows that increasing the average excise tax to PLN 9.76 for a packet of cigarettes in Poland might cause 618,000 adults to give up smoking, and 215,000 young people might be discouraged from starting smoking. It would result in a decrease in the number of premature deaths by $7.2 \%$. Additionally, income from excise tax would increase by PLN 7.1 billion. Similar problems of the taxes on tobacco products have been investigated by the scientists all over the world (Koch 2018, pp. 12-28; Motnyk, Chrobot, \& Zemła 2016, pp. 184-190; Rosiński 2014, pp. 91-102; Salti \& Brouwer 2016, pp. 161-169; Riahi, Rohani \& Rajabi 2018, pp. 767-774).

In June 2004, Poland signed the WHO Framework Convention on Tobacco Control, which was then ratified in September 2006. Pursuant to the provisions of the convention, a higher excise tax on tobacco products is one of the most effective tools to limit the distribution and usage of tobacco products. The European Union acknowledged that accepted rules concerning excise tax are the framework policy whose effect is a tax raise, which is tantamount to an increase in prices. Therefore, Poland is obliged to impose excise tax on cigarettes, and it consists of two elements: a fixed rate for 1000 cigarettes and a rate that is dependent on the value of sales, which is a percentage of the maximum retail price placed by a producer on every packet of cigarettes. The European Union also determined a minimum level of tax expressed both in a nominal form (euro) as well as a percentage of the price (Czart Ciecierski et al. 2011, p. 5).

Smoking is a phenomenon whose volume is geographically and culturally diverse. The WHO uses its own division into regions, which is used in this paper to illustrate the differences.

On average, the biggest number of cigarettes smoked per capita in 2017 was in the European WHO Region - 24.50. The Western Pacific Region comes second - 22.20. 
Third place goes to countries included in the South-East Asia Region - 19. For this reason, the territorial range of the study is limited to countries in the European Region.

Table 1. Number of cigarettes smoked daily per capita in 2017 by WHO region

\begin{tabular}{|l|c|}
\hline \multicolumn{1}{|c|}{ WHO region } & Number of cigarettes smoked daily per capita \\
\hline Africa & 7.8 \\
\hline Americas & 12.6 \\
\hline Eastern Mediterranean & 13.70 \\
\hline Europe & 24.50 \\
\hline South-East Asia & 19.00 \\
\hline Western Pacific & 22.20 \\
\hline
\end{tabular}

Source: own study based on WHO data, https://www.who.int/tobacco/global_report/2015/en/ (accessed: 20.07.2019).

\section{Tobacco consumption - the main trends}

In the countries of the European Region, where the number of cigarettes smoked daily is the biggest, smokers account for about $30 \%$ of the whole population (data from 2014). Smokers in the European Union constitute about $24 \%$ of the population, of whom $19 \%$ are heavy smokers, and $4.7 \%$ are occasional smokers. The highest percentage of smokers in 2014 was noted in Bulgaria (about 35\%), Greece (about 33\%), and Turkey (about $33 \%)$. In these countries, the biggest number of addicted smokers was also noted - $28 \%$ in Bulgaria, and 27\% in Greece and Turkey. The largest proportion of non-smokers in the population of above $80 \%$ was noted in 2014 in Sweden, Great Britain, Iceland, Finland, and Portugal. On the other hand, the number of occasional smokers is the biggest in Ireland (7.4\%), Czechia, and Denmark (7.1\%).

Table 2. Smoking of tobacco products in 2014

\begin{tabular}{|l|c|c|c|}
\hline \multicolumn{1}{|c|}{ GEO/SMOKING } & Non-smoker & Daily smoker & Occasional smoker \\
\hline EU 28 & 76.1 & 19.2 & 4.7 \\
\hline Belgium & 77.0 & 18.9 & 4.1 \\
\hline Bulgaria & 65.2 & 28.2 & 6.5 \\
\hline Czechia & 71.3 & 21.5 & 7.1 \\
\hline Denmark & 79.1 & 13.8 & 7.1 \\
\hline Germany & 78.3 & 15.9 & 5.8 \\
\hline Estonia & 72.4 & 23.5 & 4.2 \\
\hline Ireland & 78.0 & 14.6 & 7.4 \\
\hline Greece & 67.4 & 27.3 & 5.3 \\
\hline Spain & 74.7 & 23.0 & 2.4 \\
\hline France & 71.7 & 22.4 & 5.8 \\
\hline
\end{tabular}


Adam Mateusz Suchecki

Table 2. (continued)

\begin{tabular}{|l|c|c|c|}
\hline \multicolumn{1}{|c|}{ GEO/SMOKING } & Non-smoker & Daily smoker & Occasional smoker \\
\hline Croatia & 71.3 & 25.0 & 3.7 \\
\hline Italy & 77.3 & 17.8 & 3.9 \\
\hline Cyprus & 70.9 & 25.7 & 4.9 \\
\hline Latvia & 70.5 & 24.6 & 4.6 \\
\hline Lithuania & 75.0 & 20.4 & 5.8 \\
\hline Luxembourg & 79.5 & 14.6 & 1.7 \\
\hline Hungary & 72.5 & 25.8 & 4.0 \\
\hline Malta & 75.9 & 20.1 & 6.0 \\
\hline Netherlands & 74.8 & 19.1 & 5.7 \\
\hline Austria & 70.0 & 24.3 & 3.4 \\
\hline Poland & 73.9 & 22.7 & 3.2 \\
\hline Portugal & 80.0 & 16.8 & 5.8 \\
\hline Romania & 74.3 & 19.8 & 5.4 \\
\hline Slovenia & 75.8 & 18.9 & 6.7 \\
\hline Slovakia & 70.5 & 22.9 & 6.7 \\
\hline Finland & 80.8 & 12.6 & 6.9 \\
\hline Sweden & 83.3 & 9.8 & 3.0 \\
\hline United Kingdom & 82.7 & 14.2 & 6.8 \\
\hline Iceland & 81.2 & 12.0 & 7.2 \\
\hline Norway & 79.9 & 12.9 & 5.2 \\
\hline Turkey & 67.5 & 27.3 & \\
\hline Source: & 0.9 .9 & & \\
\hline
\end{tabular}

Source: own study based on the WHO data, https://www.who.int/tobacco/global_report/2015/en/ (accessed: 20.07.2019).

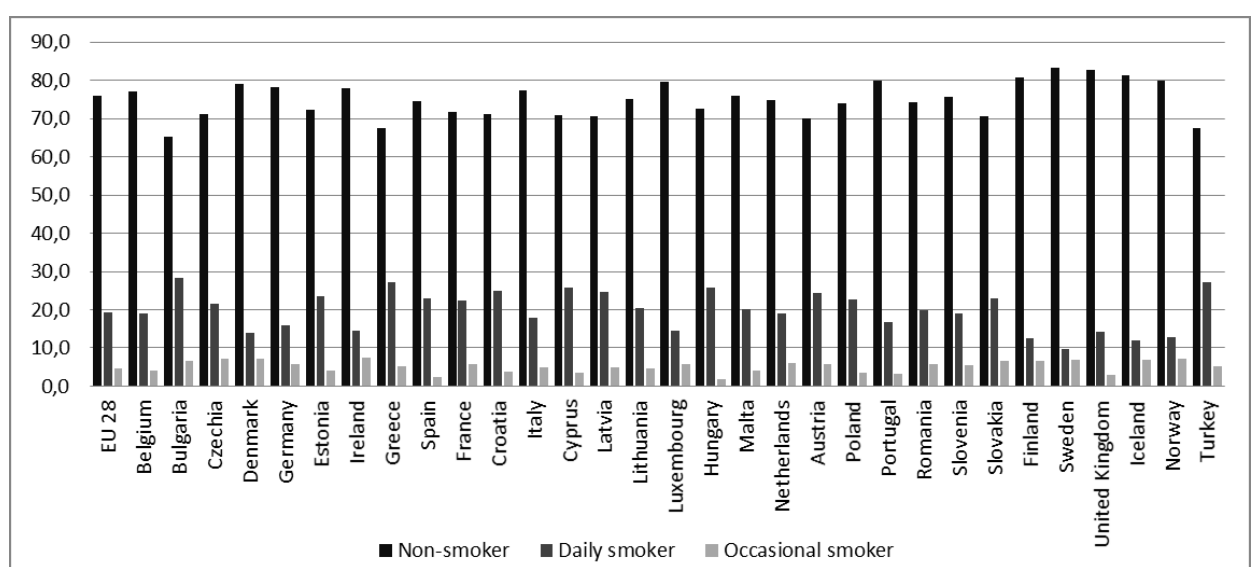

Figure 1. Smoking of tobacco products in 2014

Source: own study based on the data from Table 2.

Smoking is also a phenomenon that takes different forms, depending on the age of the smoker. According to the WHO data for 2014, the fewest addicts were noted in the age group of between 15-19. The average for the EU countries is $9.4 \%$, while the big- 
gest number of smokers was observed in Austria where up to $20 \%$ of that age group are smokers. The proportion of smokers rises with age, which is related to legal regulations concerning the availability of tobacco products for minors. In the European Union, the proportion of smokers in the 15-24 age group amounts to $15.5 \%$, for $15-29-18.8 \%$, for $18-24-19.3 \%$, for $20-24-21.3 \%$ and for $25-29-24.6 \%$. The biggest proportion of smokers in the oldest age group was noted in Bulgaria and Cyprus.

Table 3. Smoking of tobacco products by age in 2014

\begin{tabular}{|l|r|r|r|c|c|c|}
\hline \multicolumn{1}{|c|}{ GEO/AGE } & $\begin{array}{c}\text { From 15 } \\
\text { to } 19 \text { years }\end{array}$ & $\begin{array}{c}\text { From } 15 \\
\text { to } 24 \text { years }\end{array}$ & $\begin{array}{c}\text { From } 15 \\
\text { to } 29 \text { years }\end{array}$ & $\begin{array}{c}\text { From } 18 \\
\text { to } 24 \text { years }\end{array}$ & $\begin{array}{c}\text { From 20 } \\
\text { to 24 years }\end{array}$ & $\begin{array}{c}\text { From 25 } \\
\text { to 29 years }\end{array}$ \\
\hline EU 28 & 9.4 & 15.5 & 18.8 & 19.3 & 21.3 & 24.6 \\
\hline Belgium & 11.7 & 15.9 & 17.5 & 18.1 & 20.6 & 20.4 \\
\hline Bulgaria & 9.5 & 20.5 & 27.0 & 27.0 & 32.0 & 37.1 \\
\hline Czechia & 10.1 & 15.5 & 20.0 & 18.7 & 19.9 & 27.5 \\
\hline Denmark & 6.1 & 9.8 & 10.3 & 12.0 & 13.5 & 11.4 \\
\hline Germany & 6.8 & 12.1 & 15.0 & 15.1 & 17.3 & 19.7 \\
\hline Estonia & 9.3 & 21.0 & 22.9 & 28.0 & 29.5 & 25.6 \\
\hline Ireland & 7.0 & 12.7 & 15.1 & 14.7 & 17.6 & 19.5 \\
\hline Greece & 8.5 & 17.9 & 23.5 & 22.7 & 27.2 & 34.7 \\
\hline Spain & 10.2 & 18.1 & 23.4 & 23.9 & 25.5 & 32.4 \\
\hline France & 14.7 & 22.2 & 25.4 & 27.3 & 30.4 & 31.5 \\
\hline Croatia & 14.2 & 20.4 & 22.8 & 26.1 & 26.5 & 27.5 \\
\hline Italy & 7.1 & 13.2 & 16.7 & 17.3 & 19.1 & 23.2 \\
\hline Cyprus & 11.8 & 21.3 & 27.2 & 27.4 & 29.4 & 37.7 \\
\hline Latvia & 9.8 & 19.6 & 24.1 & 24.2 & 26.6 & 30.7 \\
\hline Lithuania & 7.3 & 13.7 & 18.7 & 18.6 & 20.9 & 29.3 \\
\hline Luxembourg & 10.4 & 14.0 & 14.4 & 17.3 & 17.5 & 15.1 \\
\hline Hungary & 19.9 & 27.2 & 30.2 & 30.5 & 33.7 & 35.7 \\
\hline Malta & 11.8 & 15.2 & 18.9 & 18.1 & 18.1 & 26.1 \\
\hline Netherlands & 11.2 & 17.3 & 18.9 & 21.6 & 23.0 & 22.1 \\
\hline Austria & 20.0 & 26.8 & 29.9 & 31.2 & 32.5 & 35.5 \\
\hline Poland & 6.6 & 13.4 & 16.4 & 17.4 & 19.5 & 21.0 \\
\hline Portugal & 8.0 & 15.0 & 18.2 & 19.7 & 22.0 & 24.3 \\
\hline Romania & 4.1 & 10.3 & 17.4 & 14.3 & 16.4 & 29.8 \\
\hline Slovenia & 9.7 & 15.4 & 19.5 & 19.7 & 20.3 & 25.8 \\
\hline Slovakia & 12.0 & 18.2 & 21.5 & 21.2 & 22.8 & 27.3 \\
\hline Finland & 10.8 & 11.6 & 13.7 & 13.9 & 12.3 & 17.9 \\
\hline Sweden & 5.7 & 7.4 & 7.3 & 8.9 & 9.8 & 7.1 \\
\hline United Kingdom & 8.8 & 13.4 & 15.9 & 15.3 & 16.7 & 20.3 \\
\hline Iceland & 3.2 & 7.7 & 8.6 & 10.6 & 13.6 & 10.5 \\
\hline Norway & 1.6 & 5.1 & 6.1 & 6.8 & 8.4 & 8.0 \\
\hline Turkey & 18.5 & 23.6 & 24.1 & 27.1 & 33.2 \\
\hline
\end{tabular}

Source: own study based on WHO data, https://www.who.int/tobacco/global_report/2015/en/ (accessed: 20.07.2019). 
The number of smokers differs depending on their education. In the group of people with the lowest education level in the EU, the proportion of smokers amounted to $19.5 \%$ in 2014 . The biggest percentage of people who smoke every day in that age group was noted in Estonia - 30.9\%, in Hungary - 29.2\%, and in Turkey - 28.7\%. The smallest group of smokers with the lowest education level is observed in Romania $-13.5 \%$, Finland $-14 \%$ and Sweden $-14.6 \%$.

Table 4. Smokers and non-smokers with less than primary, primary and lower secondary education in 2014

\begin{tabular}{|c|c|c|c|}
\hline GEO/SMOKING & Non-smoker & Daily smoker & Occasional smoker \\
\hline EU 28 & 77.0 & 19.5 & 3.4 \\
\hline Belgium & 73.2 & 23.0 & 3.8 \\
\hline Bulgaria & 71.5 & 24.0 & 4.6 \\
\hline Czechia & 72.5 & 19.9 & 7.6 \\
\hline Denmark & 73.3 & 20.0 & 6.7 \\
\hline Germany & 78.2 & 16.7 & 5.1 \\
\hline Estonia & 65.7 & 30.9 & 3.5 \\
\hline Ireland & 76.1 & 18.2 & 5.7 \\
\hline Greece & 73.6 & 23.2 & 3.2 \\
\hline Spain & 75.6 & 22.7 & 1.7 \\
\hline France & 75.5 & 20.6 & 3.9 \\
\hline Croatia & 77.8 & 19.9 & 2.4 \\
\hline Italy & 78.7 & 17.5 & 3.8 \\
\hline Cyprus & 79.5 & 19.1 & 1.4 \\
\hline Latvia & 71.5 & 24.1 & 4.4 \\
\hline Lithuania & 83.0 & 14.0 & 3.0 \\
\hline Luxembourg & 78.0 & 18.2 & 3.8 \\
\hline Hungary & 69.9 & 29.2 & 0.9 \\
\hline Malta & 74.4 & 22.9 & 2.7 \\
\hline Netherlands & 72.3 & 23.2 & 4.5 \\
\hline Austria & 69.4 & 26.7 & 3.9 \\
\hline Poland & 78.5 & 19.5 & 2.0 \\
\hline Portugal & 81.7 & 16.1 & 2.2 \\
\hline Romania & 82.7 & 13.5 & 3.8 \\
\hline Slovenia & 79.8 & 17.2 & 3.0 \\
\hline Slovakia & 72.2 & 21.8 & 6.0 \\
\hline Finland & 81.0 & 14.0 & 5.0 \\
\hline Sweden & 79.2 & 14.6 & 6.3 \\
\hline United Kingdom & 78.2 & 19.3 & 2.5 \\
\hline Iceland & 77.2 & 15.3 & 7.5 \\
\hline Norway & 72.0 & 19.1 & 8.9 \\
\hline Turkey & 66.1 & 28.7 & 5.1 \\
\hline
\end{tabular}

Source: own study based on the WHO data, https://www.who.int/tobacco/global_report/2015/en/ (accessed: 20.07.2019). 


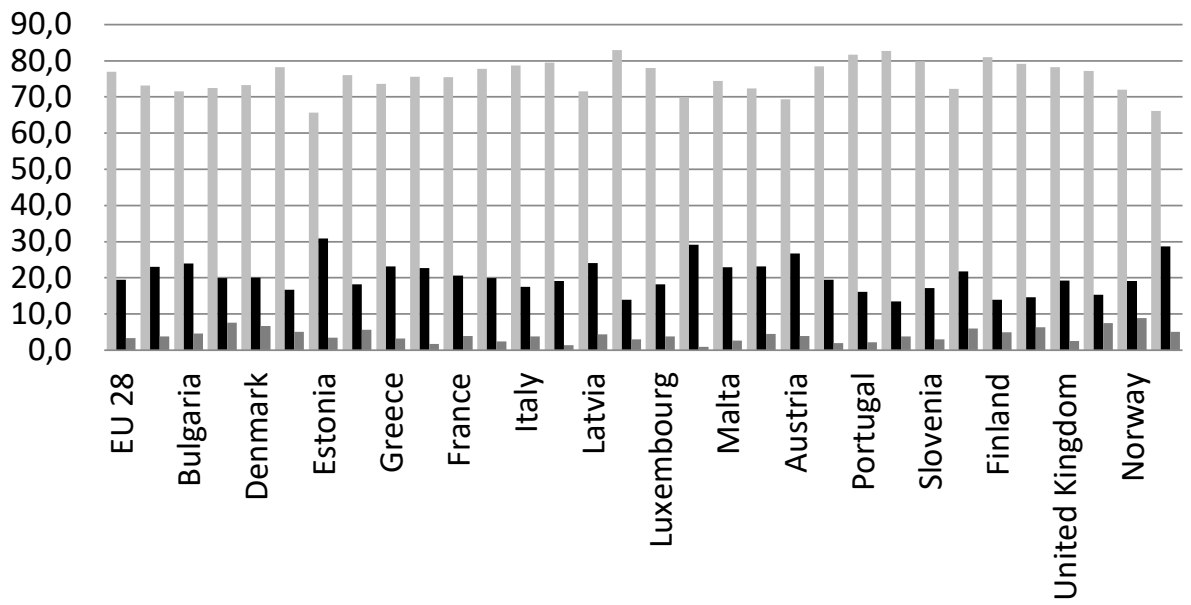

Non-smoker Daily smoker Occasional smoker

Figure 2. Smokers and non-smokers with less than primary, primary and lower secondary education in 2014

Source: own study based on the data from Table 4.

In the EU, the proportion of people who smoke every day in the group of people with secondary or higher education is greater than in the group of people with the lowest education level, and amounts to $22.7 \%$. In 2014, the biggest proportion of smokers with that level of education was noted in Bulgaria - 33.1\%, Greece - 33.1\%, and Turkey $-34.1 \%$. The country that can boast the lowest proportion of smokers in that group is Sweden, where it amounted to $10 \%$.

Table 5. Smokers and non-smokers with upper secondary and post-secondary, non-tertiary education in 2014

\begin{tabular}{|l|c|c|c|}
\hline \multicolumn{1}{|c|}{ GEO/SMOKING } & Non-smoker & Daily smoker & Occasional smoker \\
\hline EU 28 & 72.1 & 22.7 & 5.2 \\
\hline Belgium & 70.6 & 25.1 & 4.3 \\
\hline Bulgaria & 59.3 & 33.1 & 7.6 \\
\hline Czechia & 68.3 & 24.9 & 6.8 \\
\hline Denmark & 77.3 & 15.8 & 7.0 \\
\hline Germany & 75.4 & 19.0 & 5.6 \\
\hline Estonia & 68.0 & 28.0 & 4.0 \\
\hline Ireland & 73.2 & 18.5 & 8.2 \\
\hline Greece & 60.5 & 33.1 & 6.4 \\
\hline Spain & 69.7 & 26.9 & 3.4 \\
\hline France & 67.8 & 26.3 & 5.9 \\
\hline Croatia & 66.3 & 29.7 & 3.9 \\
\hline Italy & 74.9 & 19.3 & 5.8 \\
\hline Cyprus & 65.9 & 30.5 & 3.6 \\
\hline
\end{tabular}


Adam Mateusz Suchecki

Table 5. (continued)

\begin{tabular}{|l|c|c|c|}
\hline \multicolumn{1}{|c|}{ GEO/SMOKING } & Non-smoker & Daily smoker & Occasional smoker \\
\hline Latvia & 65.3 & 29.8 & 4.9 \\
\hline Lithuania & 67.6 & 27.2 & 5.2 \\
\hline Luxembourg & 75.5 & 17.8 & 6.7 \\
\hline Hungary & 68.5 & 29.8 & 7.8 \\
\hline Malta & 74.1 & 18.7 & 6.0 \\
\hline Netherlands & 72.5 & 21.5 & 6.0 \\
\hline Austria & 66.4 & 27.7 & 3.6 \\
\hline Poland & 68.6 & 27.8 & 5.7 \\
\hline Portugal & 74.0 & 20.2 & 6.7 \\
\hline Romania & 69.7 & 23.6 & 5.8 \\
\hline Slovenia & 71.8 & 22.4 & 6.5 \\
\hline Slovakia & 67.6 & 25.9 & 8.2 \\
\hline Finland & 75.1 & 16.7 & 7.9 \\
\hline Sweden & 81.5 & 10.6 & 3.4 \\
\hline United Kingdom & 79.1 & 17.5 & 7.0 \\
\hline Iceland & 79.6 & 13.3 & 6.4 \\
\hline Norway & 79.1 & 14.5 & 6.0 \\
\hline Turkey & 59.9 & 34.1 & \\
\hline Source: & 6.9 & & \\
\hline
\end{tabular}

Source: own study based on the WHO data, https://www.who.int/tobacco/global_report/2015/en/ (accessed: 20.07.2019).

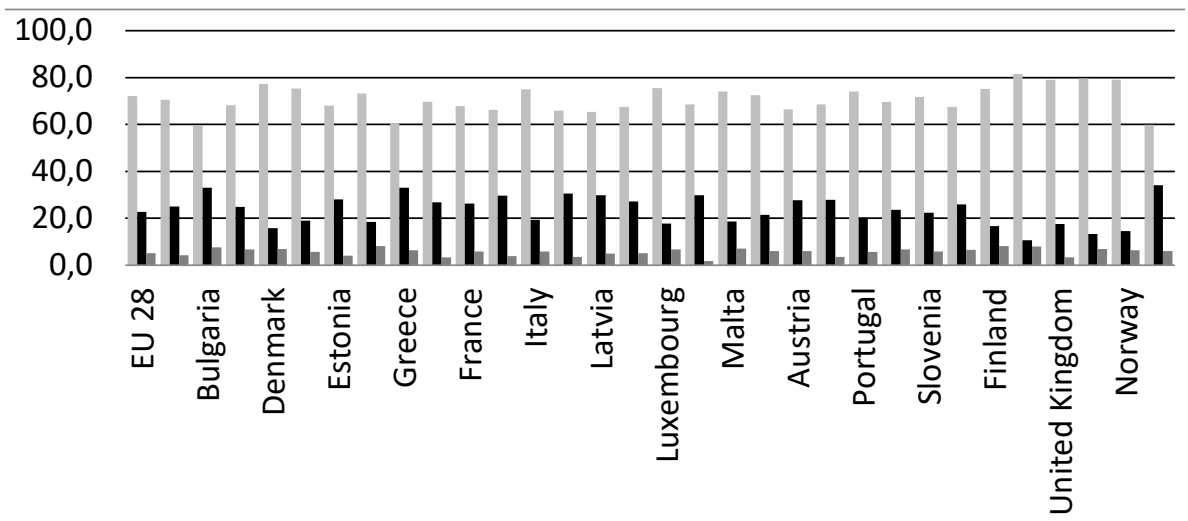

Figure 3. Smokers and non-smokers with upper secondary and post-secondary, non-tertiary education in 2014

Source: own study based on the data from Table 5.

The proportion of smokers is the lowest among people with higher education. The average rate for EU countries is $13.1 \%$. In 2014, the biggest proportion of smokers with higher education was noted in Turkey $-27.2 \%$, Greece $-26.1 \%$, Cyprus $-25.6 \%$, and Bulgaria $-23.2 \%$. Among this group, the lowest proportion of smokers was observed in Sweden $-4.6 \%$, Norway $-6.4 \%$, and Iceland $-6.6 \%$. 
Trends in Tobacco Consumption - a Comparative Analysis of WHO European Region Countries

Table 6. Smokers and non-smokers with tertiary education in 2014

\begin{tabular}{|c|c|c|c|}
\hline GEO/SMOKING & Non-smoker & Daily smoker & Occasional smoker \\
\hline EU 28 & 81.4 & 13.1 & 5.6 \\
\hline Belgium & 85.7 & 10.1 & 4.2 \\
\hline Bulgaria & 69.6 & 23.2 & 7.2 \\
\hline Czechia & 82.5 & 9.3 & 8.2 \\
\hline Denmark & 83.4 & 9.0 & 7.5 \\
\hline Germany & 82.6 & 10.7 & 6.6 \\
\hline Estonia & 80.9 & 14.2 & 4.9 \\
\hline Ireland & 83.9 & 8.3 & 7.8 \\
\hline Greece & 66.4 & 26.1 & 7.5 \\
\hline Spain & 76.5 & 20.6 & 2.9 \\
\hline France & 73.3 & 18.6 & 8.0 \\
\hline Croatia & 76.6 & 18.5 & 4.8 \\
\hline Italy & 79.1 & 14.4 & 6.6 \\
\hline Cyprus & 69.3 & 25.6 & 5.1 \\
\hline Latvia & 80.7 & 13.9 & 5.4 \\
\hline Lithuania & 82.7 & 12.7 & 4.6 \\
\hline Luxembourg & 85.7 & 8.1 & 6.2 \\
\hline Hungary & 84.7 & 13.2 & 2.1 \\
\hline Malta & 82.2 & 12.5 & 5.3 \\
\hline Netherlands & 81.3 & 10.7 & 8.0 \\
\hline Austria & 78.4 & 14.7 & 7.0 \\
\hline Poland & 83.6 & 12.3 & 4.1 \\
\hline \begin{tabular}{|l|} 
Portugal \\
\end{tabular} & 80.2 & 15.6 & 4.2 \\
\hline Romania & 71.9 & 20.5 & 7.6 \\
\hline Slovenia & 81.1 & 11.6 & 7.3 \\
\hline Slovakia & 78.6 & 13.8 & 7.6 \\
\hline Finland & 85.9 & 8.0 & 6.1 \\
\hline Sweden & 89.0 & 4.6 & 6.4 \\
\hline United Kingdom & 89.9 & 7.2 & 2.9 \\
\hline Iceland & 87.7 & 6.6 & 5.7 \\
\hline Norway & 86.8 & 6.4 & 6.9 \\
\hline Turkey & 66.4 & 27.2 & 6.4 \\
\hline
\end{tabular}

Source: own study based on WHO data, https://www.who.int/tobacco/global_report/2015/en/ (accessed: 20.07.2019).

What plays a crucial role in reducing the consumption of tobacco products is an appropriate state policy, i.e., tax and pricing policies. In all countries included in the European region, there are two forms of tax on tobacco products - VAT and excise tax. The latter can simultaneously appear in two forms - on the number of cigarettes sold (in the EU, the tax base is 1000 cigarettes) and as a percentage of their price.

In 2014, the biggest tax burden on tobacco products was noted in Great Britain $-82.16 \%$, Tukey $-82.13 \%$, Finland $-81.59 \%$, and Slovakia $-81.54 \%$. The lowest share of taxes and fees on a packet of the most popular cigarettes in a given country 
in 2014 was noted in Iceland, Sweden, and Norway, where, on average, it amounted to $56.40 \%, 68.84 \%$, and $68.83 \%$, respectively. The average share of taxes on the price of a packet of cigarettes in all European region countries is above $70 \%$, although there are significant differences in the price of a packet of cigarettes. The highest prices in 2014 were found in Norway - $\$ 15.59$, Great Britain - $\$ 12.69$, and Iceland - $\$ 10.59$. At the other end of the scale are countries such as Bulgaria, Czechia, or Lithuania, where a packet of the most popular cigarettes in 2014 cost less than $\$ 4$.

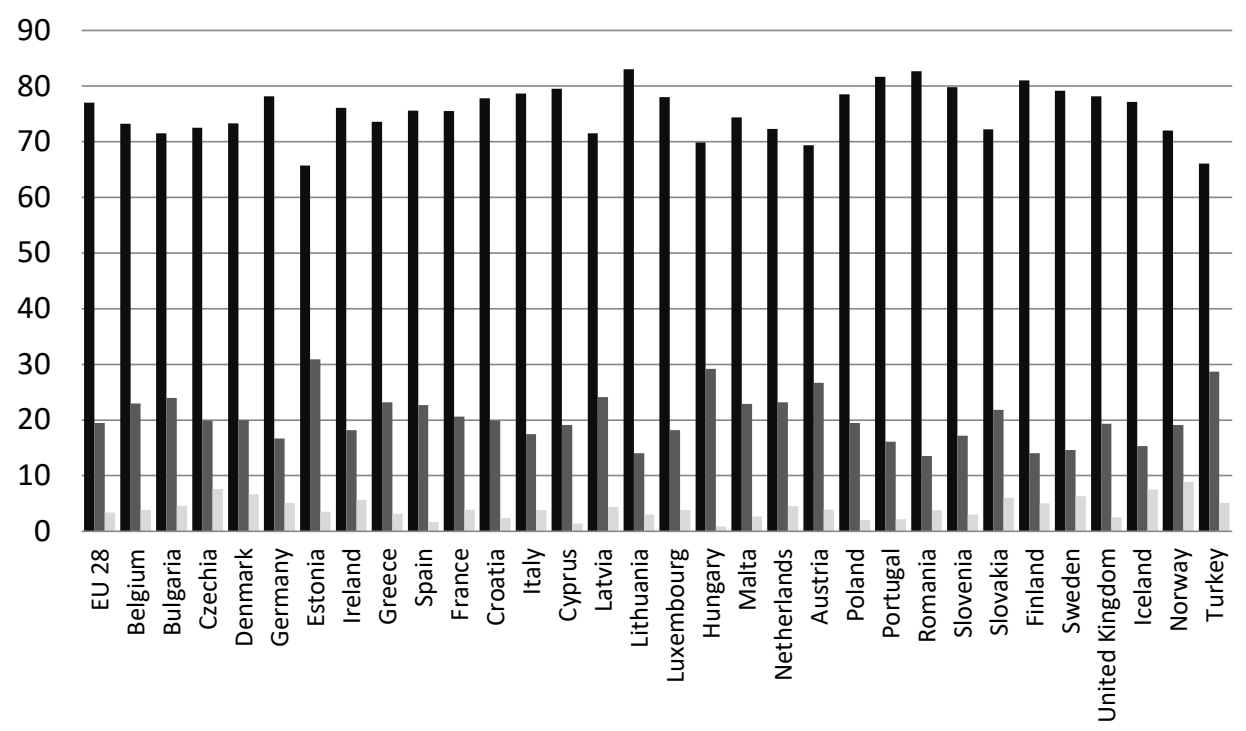

- Non-smoker Daily smoker Occasional smoker

Figure 4. Smokers and non-smokers with tertiary education in 2014

Source: own study based on the data from Table 6.

Table 7. Prices of a packet of the most popular cigarette brand in USD and their taxation (in \%) in the European region countries in 2014

\begin{tabular}{|l|r|c|c|c|c|c|c|}
\cline { 2 - 8 } \multicolumn{1}{c|}{} & $\begin{array}{c}\text { Price } \\
\text { in \$ }\end{array}$ & $\begin{array}{c}\text { Specific } \\
\text { excise in \% }\end{array}$ & $\begin{array}{c}\text { Ad Valorem } \\
\text { excise in \% }\end{array}$ & $\begin{array}{c}\text { VAT/Sales } \\
\text { Tax in \% }\end{array}$ & $\begin{array}{c}\text { Import } \\
\text { duties } \\
\text { in \% }\end{array}$ & $\begin{array}{c}\text { Other } \\
\text { taxes } \\
\text { in \% }\end{array}$ & $\begin{array}{c}\text { Total } \\
\text { tax in \% }\end{array}$ \\
\hline Belgium & 7.75 & 8.15 & 50.41 & 17.36 & 0.00 & 0.00 & 75.92 \\
\hline Bulgaria & 3.21 & 42.98 & 23.00 & 16.67 & 0.00 & 0.00 & 82.65 \\
\hline Czechia & 3.49 & 33.06 & 27.00 & 17.36 & 0.00 & 0.00 & 77.42 \\
\hline Denmark & 7.89 & 53.75 & 1.00 & 20.00 & 0.00 & 0.00 & 74.75 \\
\hline Germany & 7.32 & 35.19 & 21.74 & 15.97 & 0.00 & 0.00 & 72.90 \\
\hline Estonia & 4.68 & 26.57 & 34.00 & 16.67 & 0.00 & 0.00 & 77.24 \\
\hline Ireland & 12.84 & 50.38 & 8.72 & 18.70 & 0.00 & 0.00 & 77.80 \\
\hline Greece & 5.35 & 41.25 & 20.00 & 18.70 & 0.00 & 0.00 & 79.95 \\
\hline Spain & 6.42 & 10.04 & 51.00 & 17.36 & 0.00 & 0.00 & 78.40 \\
\hline
\end{tabular}


Trends in Tobacco Consumption - a Comparative Analysis of WHO European Region Countries

\begin{tabular}{|c|c|c|c|c|c|c|c|}
\hline & $\begin{array}{l}\text { Price } \\
\text { in } \$\end{array}$ & $\begin{array}{c}\text { Specific } \\
\text { excise in \% }\end{array}$ & $\begin{array}{l}\text { Ad Valorem } \\
\text { excise in \% }\end{array}$ & $\begin{array}{c}\text { VAT/Sales } \\
\text { Tax in } \%\end{array}$ & $\begin{array}{c}\text { Import } \\
\text { duties } \\
\text { in \% }\end{array}$ & $\begin{array}{l}\text { Other } \\
\text { taxes } \\
\text { in } \%\end{array}$ & $\begin{array}{c}\text { Total } \\
\text { tax in \% }\end{array}$ \\
\hline France & 9.37 & 13.93 & 49.70 & 16.67 & 0.00 & 0.00 & 80.30 \\
\hline Croatia & 4.04 & 18.26 & 37.00 & 20.00 & 0.00 & 0.00 & 75.26 \\
\hline Italy & 6.69 & 5.24 & 52.41 & 18.03 & 0.00 & 0.00 & 75.68 \\
\hline Cyprus & 5.35 & 27.50 & 34.00 & 15.97 & 0.00 & 0.00 & 77.47 \\
\hline Latvia & 4.01 & 34.53 & 25.00 & 17.36 & 0.00 & 0.00 & 76.89 \\
\hline Lithuania & 3.65 & 33.40 & 25.00 & 17.36 & 0.00 & 0.00 & 75.76 \\
\hline Luxembourg & 6.69 & 7.10 & 48.14 & 15.00 & 0.00 & 0.00 & 70.24 \\
\hline Hungary & 4.29 & 25.00 & 31.00 & 21.26 & 0.00 & 0.00 & 77.26 \\
\hline Malta & 6.42 & 34.38 & 25.00 & 15.25 & 0.00 & 0.00 & 74.63 \\
\hline Netherlands & 8.45 & 55.09 & 0.95 & 17.36 & 0.00 & 0.00 & 73.40 \\
\hline Austria & 6.56 & 16.33 & 41.00 & 16.67 & 0.00 & 0.00 & 74.00 \\
\hline Poland & 4.41 & 30.18 & 31.41 & 18.70 & 0.00 & 0.00 & 80.29 \\
\hline Portugal & 6.02 & 38.81 & 17.00 & 18.70 & 0.00 & 0.00 & 74.51 \\
\hline Romania & 4.39 & 37.06 & 19.00 & 19.35 & 0.00 & 0.00 & 75.41 \\
\hline Slovenia & 4.62 & 39.37 & 23.01 & 18.03 & 0.00 & 0.00 & 80.41 \\
\hline Slovakia & 3.80 & 41.87 & 23.00 & 16.67 & 0.00 & 0.00 & 81.54 \\
\hline Finland & 7.31 & 10.24 & 52.00 & 19.35 & 0.00 & 0.00 & 81.59 \\
\hline Sweden & 8.55 & 47.84 & 1.00 & 20.00 & 0.00 & 0.00 & 68.84 \\
\hline $\begin{array}{l}\text { United } \\
\text { Kingdom }\end{array}$ & 12.69 & 48.99 & 16.50 & 16.67 & 0.00 & 0.00 & 82.16 \\
\hline Iceland & 10.59 & 36.08 & 0.00 & 20.32 & 0.00 & 0.00 & 56.40 \\
\hline Norway & 15.59 & 48.83 & 0.00 & 20.00 & 0.00 & 0.00 & 68.83 \\
\hline Turkey & 3.82 & 1.63 & 65.25 & 15.25 & 0.00 & 0.00 & 82.13 \\
\hline
\end{tabular}

Source: own study based on WHO data, https://www.who.int/tobacco/global_report/2017/appendix-ix /en/ (accessed: 20.07.2019).

Comparing the prices of the most popular cigarettes in 2014 and 2018, a significant downward trend can be observed. The biggest reductions in prices were noted in Sweden $-\$ 1.11$, Norway $-\$ 1.08$, and Tukey $-\$ 1.06$. The biggest increases in prices can be observed in countries such as Iceland $-\$ 2.39$, Ireland $-\$ 1.48$, and Finland $-\$ 1.16$. The share of taxes and fees on the price of a packet of cigarettes also decreased. The most significant changes were observed in Hungary, Norway, and Germany, where the share fell by approximately 5\% in 2018 compared to 2014 .

Table 8. Prices of a packet of the most popular cigarette brand in USD and their taxation (in \%) in the European region countries in 2018

\begin{tabular}{|l|c|c|c|c|c|c|c|}
\cline { 2 - 8 } \multicolumn{1}{c|}{} & $\begin{array}{c}\text { Price } \\
\text { in \$ }\end{array}$ & $\begin{array}{c}\text { Specific } \\
\text { excise } \\
\text { in \% }\end{array}$ & $\begin{array}{c}\text { Ad Valorem } \\
\text { excise in \% }\end{array}$ & $\begin{array}{c}\text { VAT/Sales } \\
\text { Tax in \% }\end{array}$ & $\begin{array}{c}\text { Import } \\
\text { duties in \% }\end{array}$ & $\begin{array}{c}\text { Other } \\
\text { taxes in \% }\end{array}$ & $\begin{array}{c}\text { Total } \\
\text { tax in \% }\end{array}$ \\
\hline Belgium & 7.75 & 19.58 & 40.04 & 17.36 & 0.00 & 0.00 & 76.98 \\
\hline Bulgaria & 3.12 & 41.92 & 25.00 & 16.67 & 0.00 & 0.00 & 83.59 \\
\hline Czechia & 4.31 & 31.06 & 27.00 & 17.36 & 0.00 & 0.00 & 75.42 \\
\hline
\end{tabular}


Table 8. (continued)

\begin{tabular}{|c|c|c|c|c|c|c|c|}
\hline & $\begin{array}{l}\text { Price } \\
\text { in } \$\end{array}$ & $\begin{array}{c}\text { Specific } \\
\text { excise } \\
\text { in } \%\end{array}$ & $\begin{array}{l}\text { Ad Valorem } \\
\text { excise in \% }\end{array}$ & $\begin{array}{c}\text { VAT/Sales } \\
\text { Tax in \% }\end{array}$ & $\begin{array}{c}\text { Import } \\
\text { duties in \% }\end{array}$ & $\begin{array}{c}\text { Other } \\
\text { taxes in \% }\end{array}$ & $\begin{array}{c}\text { Total } \\
\text { tax in \% }\end{array}$ \\
\hline Denmark & 7.01 & 53.15 & 1.00 & 20.00 & 0.00 & 0.00 & 74.15 \\
\hline Germany & 7.51 & 30.69 & 21.69 & 15.97 & 0.00 & 0.00 & 68.35 \\
\hline Estonia & 4.99 & 32.71 & 30.00 & 16.67 & 0.00 & 0.00 & 79.38 \\
\hline Ireland & 14.32 & 50.66 & 9.04 & 18.70 & 0.00 & 0.00 & 78.40 \\
\hline Greece & 5.40 & 35.87 & 26.00 & 19.35 & 0.00 & 0.00 & 81.22 \\
\hline Spain & 5.87 & 9.88 & 51.00 & 17.36 & 0.00 & 0.00 & 78.24 \\
\hline France & 9.39 & 14.98 & 50.80 & 16.67 & 0.00 & 0.00 & 82.45 \\
\hline Croatia & 3.95 & 24.80 & 34.00 & 20.00 & 0.00 & 0.00 & 78.80 \\
\hline Italy & 6.45 & 7.01 & 51.00 & 18.03 & 0.00 & 0.00 & 76.04 \\
\hline Cyprus & 5.28 & 24.44 & 34.00 & 15.97 & 0.00 & 0.00 & 74.41 \\
\hline Latvia & 4.11 & 42.63 & 20.00 & 17.36 & 0.00 & 0.00 & 79.99 \\
\hline Lithuania & 4.40 & 31.47 & 25.00 & 17.36 & 0.00 & 0.00 & 73.83 \\
\hline Luxembourg & 6.22 & 7.13 & 46.65 & 14.53 & 0.00 & 0.00 & 68.31 \\
\hline Hungary & 4.54 & 26.02 & 25.00 & 21.26 & 0.00 & 0.00 & 72.28 \\
\hline Malta & 6.45 & 38.91 & 23.40 & 15.25 & 0.00 & 0.00 & 77.56 \\
\hline Netherlands & 8.22 & 49.46 & 5.00 & 17.36 & 0.00 & 0.00 & 71.81 \\
\hline Austria & 6.45 & 21.09 & 37.50 & 16.67 & 0.00 & 0.00 & 75.26 \\
\hline Poland & 4.25 & 26.68 & 31.41 & 18.70 & 0.00 & 0.00 & 76.79 \\
\hline Portugal & 5.87 & 37.96 & 15.00 & 18.70 & 0.00 & 0.00 & 71.66 \\
\hline Romania & 4.43 & 38.60 & 14.00 & 15.97 & 0.00 & 0.00 & 68.57 \\
\hline Slovenia & 4.34 & 38.55 & 22.61 & 18.03 & 0.00 & 0.00 & 79.19 \\
\hline Slovakia & 3.87 & 37.45 & 23.00 & 16.67 & 0.00 & 0.00 & 77.12 \\
\hline Finland & 8.47 & 16.06 & 52.00 & 19.35 & 0.00 & 0.00 & 87.41 \\
\hline Sweden & 7.44 & 47.38 & 1.00 & 20.00 & 0.00 & 0.00 & 68.38 \\
\hline United Kingdom & 12.37 & 46.22 & 16.50 & 16.67 & 0.00 & 0.00 & 79.39 \\
\hline Iceland & 12.98 & 36.13 & 0.00 & 19.35 & 0.00 & 0.00 & 55.49 \\
\hline Norway & 14.51 & 43.97 & 0.00 & 20.00 & 0.00 & 0.00 & 63.97 \\
\hline Turkey & 2.76 & 3.11 & 63.00 & 15.25 & 0.00 & 0.00 & 81.37 \\
\hline
\end{tabular}

Source: own study based on WHO data, https://www.who.int/tobacco/global_report/2017/appendix-ix len/ (accessed: 20.07.2019).

\section{Conclusion}

In most countries, the consumption and trading of tobacco products are subject to public sector control. This control aims to provide an appropriate amount of the state budget income, but it also involves reducing the consumption of tobacco as an undesired good. These two objectives are mutually exclusive, yet, having taken into consideration the costs of treatment of illnesses caused by smoking (both active and passive), they are much higher than the budget income achieved from sales of tobacco 
products. State interventionism concerning tobacco is most visible in developed countries such as the US, Canada, and European Union countries. Developing countries and Asian countries also have also started to introduce regulations concerning tobacco consumption on a large scale in response to the negative effects of nicotinism.

What seems to be the primary economic tool used to combat nicotinism is price control. Any type of regulation that should increase the price of a packet of cigarettes, such as introducing a uniform structure of excise tax in the EU, or raising VAT rates on tobacco products, at least in theory, reduces their consumption. Analysis suggests that levels of tax rates and the price of a packet of cigarettes do not affect the percentage of tobacco addicts. This is because of the substitution effect - consumers switch to cheaper substitutes, such as cut smoking tobacco ("roll-your-own"), as confirmed by studies conducted in Spain, or tobacco products from illegal sources. Increasing cigarette prices through appropriate legal-economic regulations have the most significant impact on anti-nicotine preventive measures among young people by creating a kind of economic barrier. As can be seen from other studies, the biggest number of nicotine-addicts was noted in the group of people of working age with secondary or post-primary education.

Apart from the abovementioned intervention methods, the public sector can also affect the situation through other legislative actions such as a total ban on smoking in public places outside designated areas, which is becoming very common. This type of restriction, along with pricing and tax policies concerning tobacco products, as well as educational and preventive programs, are probably the only effective methods to combat nicotinism. A problem related to using these solutions can be the cultural roots of smoking that are particularly visible in the countries of Sothern Europe. The increasing trend in the consumption of tobacco products, mostly in developed countries, is the rising popularity of cigarette alternatives, such as hand-rolled cigarettes. This could be the reason why tobacco consumption did not fall in the European region, although prices were rising.

\section{References}

Blecher, E. (2015), Taxes on tobacco, alcohol and sugar sweetened beverages: Linkages and lessons learned, "Social Science \& Medicine", pp. 136-137. https://doi.org/10.10 16/j.socscimed.2015.05.022

Burguillo, M., Romero-Jordán, D., Sanz-Sanz, J.-F. (2019), Efficacy of the tobacco tax policy in the presence of product heterogeneity: A pseudo-panel approach applied to Spain, "Health Policy", pp. 1-8. https://doi.org/10.1016/j.healthpol.2019.06.011

Czart Ciecierski, C., Cherukupalli, R., Weresa, M. (2011), Ekonomiczne aspekty palenia tytoniu i opodatkowania wyrobów tytoniowych w Polsce, International Union Against Tuberculosis and Lung Disease, Paris.

https://tobaccoatlas.org/ (accessed: 20.07.2019).

https://www.who.int/tobacco/global_report/2015/en/ (accessed: 20.07.2019). 
https://www.who.int/tobacco/global_report/2017/appendix-ix/en/ (accessed: 20.07.2019). Hu, T.W., Mao, Z. (2002), Effects of cigarette tax on cigarette consumption and the Chinese economy, "Tobacco Control", Vol. 11. https://doi.org/10.1136/tc.11.2.105

Jami, M., Kostova, D., Mbulo, L., Benjakul, S., Kengganpanich, M., Andes, L. (2017), Changes in cigarette prices, affordability, and brand-tier consumption after a tobacco tax increase in Thailand: Evidence from the Global Adult Tobacco Surveys, 2009 and 2011, "Preventive Medicine", Vol. 105. https://doi.org/10.1016/j.ypmed.20 17.05.027

Koch, S.F. (2018), Quasi-experimental evidence on tobacco tax regressivity, "Social Science \& Medicine", Vol. 196. https://doi.org/10.1016/j.socscimed.2017.11.004

Motnyk, M., Chrobot, M., Zemła, B. (2016), Wybrane konsekwencje ekonomiczne izdrowotne konsumpcji tytoniu dla budżetu państwa i sektora publicznego, "Polski Przegląd Nauk o Zdrowiu", Vol. 2.

Riahi, M., Rohani, H., Rajabi, N. (2018), Tobacco tax and price in the developed and developing countries in the World, "Data in Brief", Vol. 20. https://doi.org/10.1016 /j.dib.2018.06.100

Rosiński, R. (2014), Istota i analiza struktury opodatkowania wyrobów tytoniowych w krajach Unii Europejskiej, "Finanse, Rynki Finansowe, Ubezpieczenia", Vol. 68.

Salti, N., Brouwer, E. (2016), The health, financial and distributional consequences of increases in the tobacco excise tax among smokers in Lebanon, "Social Science \& Medicine”, p. 170. https://doi.org/10.1016/j.socscimed.2016.10.020

Samochowiec, J., Rogoziński, D., Hajduk, A., Skrzypińska, A. (2001), Diagnostyka, mechanizm uzależnienia i metody leczenia uzależnienia od nikotyny, "Alkoholizm i Narkomania", Vol. 14 (3).

\section{Streszczenie}

\section{Wpływ instrumentów ekonomicznych na popyt, podaż i konsumpcję wyrobów tytoniowych - analiza porównawcza dla krajów regionu europejskiego WHO}

Konsumpcja tytoniu podobnie jak innych substancji psychoaktywnych prowadzi najczęściej do uzależnienia stanowiąc poważny problem zdrowotny współczesnych społeczeństw. W licznych badań prowadzonych na świecie wskazuje się, iż długotrwałe palenie papierosów lub tytoniu jest odpowiedzialne za wiele chorób niezakaźnych, między innymi raka płuc, raka krtani prowadząc do przedwczesnych zgonów. Z tego powodu rośnie również ryzyko zgonów z powodu chorób kardiologicznych oraz układu trawiennego. Uzależnienie od nikotyny może również prowadzić do inwalidztwa (w wyniku tracheotomii) lub znacznego obniżenia odporności organizmu. W celu ograniczenia negatywnego wpływu konsumpcji tytoniu zagwarantowania zrównoważonego rozwoju rządy poszczególnych państw, zarówno tych rozwiniętych jak i rozwijających się prowadzą dwukierunkową polityką ograniczającą produkcję i konsumpcję wyrobów tytoniowych poprzez stosowanie odpowiednich instrumentów finansowych jak i wdrażanie różnych programów zdrowotnych przeciwdziałających 
uzależnieniu. Wszelkie działania podejmowane na różnych szczeblach decyzyjnych związane są często z polityką ekonomiczną, finansową, w tym fiskalną danego państwa. Upowszechnienie się poglądów, iż uwarunkowania nieracjonalnych zachowań konsumentów podlegają działaniu praw ekonomicznych i można je odnosić do analiz dotyczących ograniczania konsumpcji i produkcji wyrobów tytoniowych. Przedmiotem szeroko zakrojonych badań światowych są ekonomiczne analizy wpływu opodatkowania tytoniu na ceny wyrobów tytoniowych, podaż i popyt.

Zasadniczym celem artykułu jest prezentacja wykorzystania takich instrumentów jak cena (nie tylko w wyrażeniu) oraz różne formy opodatkowania wyrobów tytoniowych (podatek akcyzowy, podatek ad valorem) na kształtowanie się konsumpcji, nierówności dochodowych ludności oraz na ograniczenia produkcji koncernów tytoniowych i rozwój nielegalnych źródeł dystrybucji tych produktów. Rozważania teoretyczne zostaną uzupełnione wynikami badań prezentowanymi m.in. przez World Health Organization - WHO.

Słowa kluczowe: tytoń, podatek, polityka publiczna 